\title{
Study on the Intercultural Communication Abilities of Business English in Higher Vocational Colleges under One Belt One Road (OBOR) Environment -- A Case Study of Zhejiang Province
}

\author{
Aimei Yang \\ Wenzhou Vocational \& Technical College, Wenzhou 325000, China. \\ 334710101@qq.com
}

Keywords: "One belt one road", personnel training, pal pattern, deepen the practice.

\begin{abstract}
The exchanges between China and other countries along the routes are on the rise by initiating the "One Belt One Road". It also puts forward higher requirements for the intercultural communication abilities of English majors in higher vocational colleges. This paper focuses on the current situation of higher vocational colleges education in Zhejiang province, then explores the existing problems and causes, and finally proposes some practical measures. The vigorous development of the transit trade gives rise to the building of OBOR integration of the construction of local governments and enterprises which could gain more profits in the construction of it.
\end{abstract}

\section{Introduction}

"One Belt One Road" (OBOR) is short for the "Silk Road Economic Belt" and the "21st century maritime silk Road". At present, with slowly recovering of the global economy, strengthening regional co-operations will be an important driving force for world economic development. The establishment of free trade zones in countries and regions along the OBOR will open a new breakthrough for Chinese enterprises to further integrate into the global economy.

\section{Analysis on the Demand of Business English Talents under the Background of "One Belt One Road"}

Under the background of "One Belt One Road", the enterprises have higher requirements on the professional quality of business English talents. Along the One Belt One Road economic belt, the countries are numerous, and they appear multinational, multi-type and muti-religious characteristics, therefore, it's important that the talents have rich knowledge of the society and humane knowledge and can carry on the cross-cultural communication to smooth project implementation and the realization of strategic goals. In the face of changing international business environment, business English talents should be quickly adapt to the cultural differences and enhance their cross-cultural communication abilities which makes them communicate and exchange effectively in intercultural business activities in order to ensure that the project is making good progress.

\section{Current Problems and Causes of Business English Education in Higher Vocational Colleges}

3.1 Existing problems.

\subsubsection{Diversities of Languages and Differences in English Variants.}

Under the "One Belt One Road" strategy, more than 50 countries have expressed their willingness to cooperate with China on economic projects. Therefore, the communicators should first have a certain ability of speech recognition and understanding. The construction of "One Belt One Road" involves nearly 50 kinds of National Common Languages. First, English is needed to pave the way. Although English can be used as a National Common Language, businesses from different countries hold all kinds of English phonetics, which will produce English variants and cause business 
communication barriers. It requires our students to master as many languages as possible, to actively participate in business activities, and to have the abilities of compound language!

\subsubsection{Countries along the Silk Road Economic Belt Are Short of National Conditions and Cultures.}

In the international strategy of "going out", different cultural backgrounds of foreign enterprises get together, although languages are not communication disorders, each individual has different cultural habits, he may show the difference ways of thinking in business behaviors. The main reason is that there is no construction of national conditions and cultural system and no good communication between countries' conditions and cultures.

\subsection{Causes of the Problem.}

\subsubsection{Cultural Factors.}

It can be divided into three parts. The first one is the difference of thinking mode, for example, the culture of English-speaking countries emphasizes logical analysis, while Chinese culture emphasizes intuition. The second part is the pragmatic obstacle. Despite the various reforms of English teaching in China, it only gives the priority to grammar teaching. Teachers may focus on grammar and vocabulary teaching only, which is short of the cultivation abilities of language application. And the pragmatic knowledge is neglected by them also. The third one is the cultural background understanding obstacle. Every country or nation has its own histories, traditional habits and customs, mythologies and religions. They play a vital role in the formation and development of the nations and affect the acceptance of foreign cultures.

\subsubsection{Human factors.}

Business English majors in higher vocational colleges are short of cultural background knowledge with low humanistic quality, low attention to language and culture and low enthusiasm for learning. Although most of the professional teachers of business English have a solid English language foundation, due to lack of real-world experience, professional knowledge and skills of business, international views, cultural sensitivity and cross-cultural communicating competence.

\section{Current Situations of Education in Business English in Zhejiang Vocational College}

\subsection{Advantages.}

\subsubsection{Goals are clear.}

While recognizing the importance of English skills, vocational colleges in Zhejiang province also emphasize the importance of cultivating creative talents. For example, in applied English major in Yiwu industrial and commercial college, they cultivate extensive humanistic knowledge (especially cross-cultural knowledge), practical professional knowledge and interpersonal communication abilities. Their graduates with innovative spirit and practical abilities to cultivate specialized personnel with high quality can engage in translation, trading practice of foreign countries, international e-commerce, foreign secretary, etc. in the trade industries and other departments.

\subsubsection{The Talent Training Model Is Feasible.}

On school-running ideas, based on the curriculum system, taking the humanist concept of general education and innovation education as the guide and cultivating comprehensive qualities as the core, we strengthen the education of humanities and social sciences such as literature, history, philosophy and art, in order to realize the humanities foundation of general education. At the same time, it aims to cultivate students' comprehensive business English talents with both morality and talent and global awareness, and cultivate their understanding and tolerance of different cultures, also enhance their global awareness. In terms of teaching methods, "interactive teaching" and "exploratory learning" are mainly adopted to improve students' innovative thinking abilities and collaborative problem-solving abilities. On course system, on the basis of the English language skills, taking construction of the humanities as the most important and information technology as the platform, we make a core of foreign language together with professional courses (i.e., English together with economic and trade English, business administration, etc.) and a stepwise compound curriculum system with intercultural business exchange practice base as auxiliary. On the evaluation system, we establish a summative 
and formative evaluation with the combination of a new system of comprehensive evaluation, and highlight the proportion of formative assessment in teaching evaluation, also pay more attention to the learning processes and effects.

\subsection{Disadvantages.}

\subsubsection{The Targets of Business English in Higher Vocational Colleges Are Unclear.}

Business English courses in higher vocational colleges should strengthen students' ability to use business English and improve their communicative abilities. However, English language and dealing with business problems in the English classroom teaching is short of continuity and consistency, and there are divisions between languages and business, which is hard to meet the needs of society and enterprises. It is the waste of talent cultivation.

\subsubsection{Business English Teaching Is Too Traditional.}

The contents of higher vocational business English are not related to production practice. Taking her school as a respondent, the author used the questionnaires and visited the relevant people to track the employment situation of graduates in the past three years and investigate the demand of enterprises for cross-border e-commerce talents. Among them, according to the statistical analysis of recycling questionnaire, there are $82 \%$ of the students who have already lost the interest of the same PPT interpretation model or role play activities which causes low class participation enthusiasm and motivation. Students master the knowledge of business English, but can't put the knowledge into practical application.

\section{Optimization strategies and countermeasures}

\subsection{Establish Strong Recognition of Business English Students From the Learning Attitude. 5.1.1 Creating Suitable Language Atmosphere.}

When conducting intercultural communication, only having the ability to use language and communicate with others cannot meet the communicative needs. We should also have an in-depth understanding of the country, society and culture of the target. Intercultural communication courses aim at cultivating students' intercultural communication abilities, and solving problems encountered in intercultural communication, then improving the quality of intercultural communication activities. Therefore, in the teaching process, students should be exposed to many different cultures. They need to understand and adapt to the differences between different cultures, and learn to appreciate the value of different cultures. For example, holding English clubs or English corners to increase the chance of communicating with foreign teachers and other foreigners, and conducting lectures regularly to introduce British and American cultural, also inviting experts with more experience on foreign trade enterprises to teach practical intercultural communication cases and other activities which let the student's initiative to understand the different cultures.

\subsubsection{Cultivate Students' Language Attitude and Willingness of Communication.}

Business English major students with abilities to cross-cultural communication cover a wide range, including the ability of using language, communication ability, the ability of adapting to the differences between the cultures and thinking ability in the case of business activities. Compared with the domestic market, the overseas market is more complex and changeable which gives students a stronger sense of strangeness. Therefore, the international business English talents who meet the demand of OBOR strategy need to have a stronger national self-confidence and pride and higher ability in cross-cultural communication, also the courage to participate in international competition, together with the enthusiasm of participation in international cooperation and sufficient mental capacity and unremitting struggling spirit. In the process of cultivating the intercultural communication ability of business English majors, besides the communication ability, it is also necessary to emphasize the cultivation of their communicative intentions and language attitudes.

\subsection{Innovate Education Model and Its Media.}

\subsubsection{Introducing PBL Teaching Model.}

PBL (problem -based learning, guided by questions) which began in the late 19th century is a kind of teaching theory. It put forward for the first time by the American professor of neurology--Barrow 
in Mac-master university of Canada, now it has become a popular way of teaching. It emphasizes students' exploring a way of learning, what means that, placing your learning to a complex and meaningful scenario relied on the learners' active information search information, then sorting out and analyzing, also organizing group discussion, together with forming the independent learning ability and problem solving skills. Therefore, PBL is considered a special use of English education based on content of ESL (English as a second language teaching) education, and a way of education to assist as multimedia auxiliary of EFL (English as a foreign language teaching). Under the guidance of PBL teaching method and combined with cross-border e-commerce platform, a set of methods which is suitable for business English classroom teaching of vocational students is summarized through constant exploration and practice. Taking Jiaxing vocational technical college business English as an example, they chose the students who entered in 2014 to join in the pilot project of "Cross-Border Electronic Commerce Orders" which named "excellent class". It takes the lead in the implementation of PBL teaching method and has achieved good results.

\subsubsection{Make Full Use of Multimedia.}

Teachers organize students to watch the "One Belt One Road" publicity program in a planned way, and access to the knowledge of foreign cultures through various channels. They also arrange students to search the Internet to download and publicity programmers associated culture material or as part of OROB cultural exchange as homework, which let the students improve their oral English ability through the form of video playback or PPT show, and self-study through the school multimedia devices or their spare time to play some English training films, English drama, etc. The teachers should give those chances to direct contact with the cultural knowledge of English countries, and expand culture field of vision of students. At the same time, we are looking for e-commerce platforms that are in line with the current trend and make use of the convenient conditions of network to spread cross-border trade more and more widely around the world.

\section{Conclusion}

Colleges and universities should cooperate with standard requirements in "National Standards for Undergraduate Teaching Quality of Business English Majors in Institutions of Higher Learning”, and timely change to the business English professional talents training scheme. Based on the theory of ESP demand, emphasize further the cultivation of innovative talents combined with local regional economic development. At the same time, in higher vocational English teaching, it is an important way to improve students' comprehensive English application abilities and achieve the integration of production and teaching. In Zhejiang province, especially the training of cross-border e-commerce talents and cross-border e-commerce English innovation talents, both would provide a talent reserve for the sustainable development of economy of Zhejiang.

\section{References}

[1] English section of the foreign language teaching steering committee of institutions of higher learning. English teaching syllabus for college English majors [Z]. Beijing: foreign language teaching and research press; Shanghai: Shanghai foreign language education press, 2000.

[2] Hu Winching, GAO Yichang. Foreign language teaching and culture [M]. Changsha: Hunan Education press, 1995.

[3] Jian Fuxin. Intercultural communication [M]. Shanghai: Shanghai Foreign Language Education press, 1997.

[4] Wen Qi fang. The relationship between learner controllable factors and English performance [M]. Xi 'an: Shanxi Normal University press, 2004.

[5] Zhang Hong ling. Intercultural foreign language teaching [M]. Shanghai: Shanghai Foreign Language Education press, 2007. 